\title{
Peran Digital Marketing dalam Upaya Peningkatan Omset Penjualan di Era Pandemi Covid-19 (Studi Kasus : UKM Deva Bag Desa Jiken Sidoarjo)
}

\author{
Fauziatul Isnainiyah $^{1^{*}}$, Nabiela Naily ${ }^{2}$, Zainal Muttaqim ${ }^{3}$ \\ ${ }^{1}$ Jurusan Ekonomi Syariah, Fakultas Ekonomi dan Bisnis Islam \\ Universitas Islam Negeri Sunan Ampel Surabaya \\ ${ }^{2}$ Jurusan Keluarga (Ahwalus Syakhsiyah), Fakultas Syariah dan Hukum \\ Universitas Islam Negeri Sunan Ampel Surabaya \\ ${ }^{3}$ Jurusan Ekonomi Syariah, Fakultas Ekonomi dan Bisnis Islam \\ Universitas Islam Negeri Sunan Ampel Surabaya \\ *Korespondensi Email: fauziatulisnainiyah13@gmail.com
}

\begin{abstract}
ABSTRAK
WHO menyatakan bahwa virus Covid-19 adalah pandemi, sehingga pemerintah Indonesia telah menerapkan berbagai kebijakan untuk memutus mata rantai penyebaran COVID-19. Larangan berkerumun atau berkumpul termasuk salah satunya, sehingga semua harus dilakukan secara online dan di kerjakan di rumah. Pandemi ini sangat berdampak buruk terhadap keberlangsungan ekonomi, terdapat banyak masyarakat mengalami penurunan penghasilan akibat pandemic Covid-19 ini, bahkan banyak juga masyarakat yang kehilangan pekerjaan. Salah satu sektor ekonomi yang merasakan dampak pandemic yaitu Usaha Kecil Menengah (UKM). Tidak terkecuali UKM Deva Bag Desa Jiken Kecamatan Tulangan Kabupaten Sidoarjo. Dengan kondisi pandemic saat ini tentunya UKM harus tetap bertahan sehingga dibutuhkan strategi alternative pemasaran. Oleh karena itu, dibutuhkan strategi seperti digital marketing yang meliputi penjualan melalui sosial media hingga marketplace dalam upaya peningkatan omset UKM. Sehingga penelitian ini, dilakukan dengan tujuan memberikan edukasi tentang digital marketing terhadap UKM Deva Bag di Desa Jiken Kecamatan Tulangan. Metode yang dilakukan dengan wawancara dan action research berupa penyuluhan dan edukasi tentang digital marketing. Kegiatan terlaksana secara baik dan teratur, UKM Deva Bag Desa Jiken sangat antusias ingin mengetahui lebih mendalam bagaimana sistem/strategi digital marketing.
\end{abstract}

Kata Kunci: Ekonomi, UKM, Digital Marketing, Covid-19

\section{ABSTRACT}

WHO states that the Covid-19 virus is a pandemic, so the Indonesian government has implemented various policies to break the chain of spread of COVID-19. The prohibition of gathering or gathering is one of them, so everything must be done online and done at home. This pandemic has had a very bad impact on economic sustainability, many people have experienced a decline in income due to the Covid-19 pandemic, and many have even lost their jobs. One of the economic sectors that is feeling the impact of the pandemic is Small and Medium Enterprises (SMEs). The Deva Bag SMEs is no exception in Jiken Village, Tulangan District, Sidoarjo Regency. With the current pandemic conditions, of course, SMEs must survive so an alternative marketing strategy is needed. Therefore, strategies such as digital marketing are needed which include sales through social media to marketplaces in an effort to increase SME turnover. So this research was conducted with the aim of providing education about digital marketing to Deva Bag SMEs in Jiken Village, Tulangan Regency. The method used is interviews and action research in the form of counseling and education about digital marketing. The activity was carried out properly and regularly, 
Deva Bag SMEs Desa Jiken was very enthusiastic about wanting to know more about the digital marketing system/strategy.

Keywords: Economy, SMEs, Digital Marketing, Covid-19

\section{PENDAHULUAN}

\section{Analisis Situasi}

Indonesia dikejutkan dengan wabah penyakit virus Covid-19 yang berasal dari China sejak tahun 2020. Virus ini menyebar di Indonesia yang menyebar pada tahun 2020 hingga saat ini. Dengan adanya wabah ini, hampir seluruh negara - negara di dunia merasakan dampak di sektor kesehatan dan ekonomi. Pada bulan Maret 2020 WHO mengumumkan bahwa Covid-19 sebagai pandemic, yang diikuti jumlah kasus yang melonjak di Indonesia.

Pemerintah Indonesia menetapkan beberapa kebijakan untuk mengantisipasi pelonjakan angka kasus yang terkonfirmasi wabah virus seperti kebijakan yang diterapkan pemerintah pusat hingga tingkat kota dan kabupaten dengan tujuan pemutusan rantai penyebaran virus covid-19 yaitu dengan Pembatasan Sosial Berskala Besar (PSBB), School From Home (SFH) yaitu sekolah secara daring dari rumah masing-masing dan Work From Home (WFH) bagi beberapa sektor pekerjaan. Seiring berjalannya waktu, pandemic masih belum usai dan WHO menyatakan bahwa muncul varian baru dari Covid-19 yakni Alfa, Beta, Gamma dan Delta. Oleh karena lonjakan kasus Covid-19 ini, pemerintah membuat kebijakan terbaru yang akan berlaku mulai 3 Juli hingga 26 Juli 2021 yakni Pemberlakuan Pembatasan Kegiatan Masyarakat (PPKM) Darurat.

Angka lonjakan kasus positif Covid-19 di Indonesia hingga Juli 2021 mencapai 2,91 juta orang positif, 2,29 juta sembuh dan 74.920 meninggal (Komite Penanganan Covid-19 dan Pemulihan Ekonomi Nasional, 2021). Dengan adanya lonjakan angka kasus Covid-19, tidak hanya bencana pada sektor kesehatan, namun juga menimbulkan kekacauan pada sektor perekonomian sehingga sektor tersebut mengalami dampak yang signifikan. Kondisi tersebut berdampak ke berbagai sektor ekonomi, salah satunya yaitu keberlangsungan UKM di Kabupaten Sidoarjo. UKM merupakan sebuah pondasi ekonomi dalam pemulihan ekonomi. Potensi yang cukup signifikan dalam penyerapan tenaga kerja perlu ditingkatkan secara maksimal sehingga mengurangi dampak pengangguran yang ada dan dapat memanfaatkan sumber daya alam local. Namun, dengan adanya wabah virus ini Indonesia mengalami penurunan ekonomi yang cukup tajam dikarenakan banyaknya UKM yang merasakan dampak kerugian. Sidoarjo merupakan salah satu Kabupaten di Jawa Timur yang mempunyai banyak industry dan UKM. Berdasarkan data Covid-19 Kabupaten Sidoarjo, pada tanggal 21 Juli 2021 sudah mencapai angka 15.715 orang yang positif Covid-19, 12.084 sembuh dan 652 meninggal (Dinas Komunikasi dan Informatika Kabupaten Sidoarjo, 2021). Dampak yang dirasakan UKM disebabkan adanya kebijakan Pemerintah yakni Pembatasan Sosial Berskala Besar (PSBB) dan Pemberlakuan Pembatasan Kegiatan Masyarakat (PPKM) Darurat.

Berdasarkan data Tahun 2020 dari Dinas Koperasi dan UKM (DISKOPUKM) Jawa Timur, Kabupaten Sidoarjo memiliki 248.306 UKM. Sidoarjo yang didominasi oleh UKM yang menjadi sumber perekonomian daerah juga mengalami dampak kerugian dari wabah virus ini. Tidak hanya pemilik UKM yang mengalami kerugian pendapatan akibat wabah virus tetapi juga karyawan yang harus mengalami pengurangan karyawan. Oleh karena permasalahan terebut mengharuskan pemangku kepentingan untuk bekerja sama dalam mempertahankan keberlangsungan dan kelanjutan UKM dengan tujuan melahirkan kebangkitan UKM dalam perekonomian. 
UKM di Indonesia berkontribusi besar terhadap perekonomian nasional dari tahun ke tahun pada Produk Domestik Bruto (PDB). Tahun 2020 merupakan tahun terendah sejak 2010 dimana kontribusi Usaha Mikro, Kecil, dan Menengah (UMKM) terhadap Produk Domestik Bruto (PDB) mengalami penurunan hingga $38,14 \%$ dengan jumlah sebesar $37,3 \%$ (Kementerian Koperasi dan Usaha Kecil dan menengah, 2020). Selain kontibusi terhadap PDB Indonesia, UKM juga membantu dalam pengurangan kemiskinan dengan adanya lapangan pekerjaan.

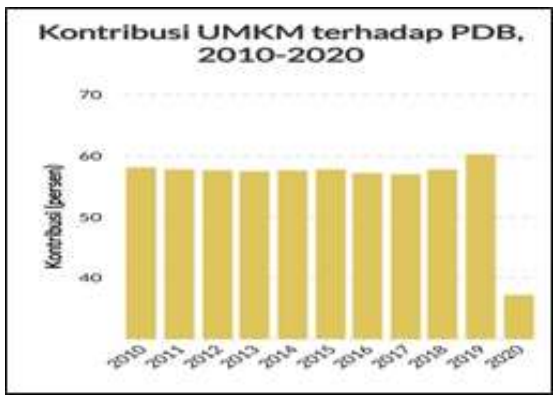

Gambar 1 Kontribusi UMKM dari 2010-2020

Di era pandemic Covid-19, jika UMK ingin bisnisnya bertahan maka memerlukan strategi dengan memanfaatkan perkembangan digital. Pemanfaatan perkembangan era digital dapat dilakukan dengan melakukan pemasaran atau biasa disebut dengan digital marketing. Sebagai contoh, penggunaan internet di Indonesia sering digunakan dalam berbagai aspek.

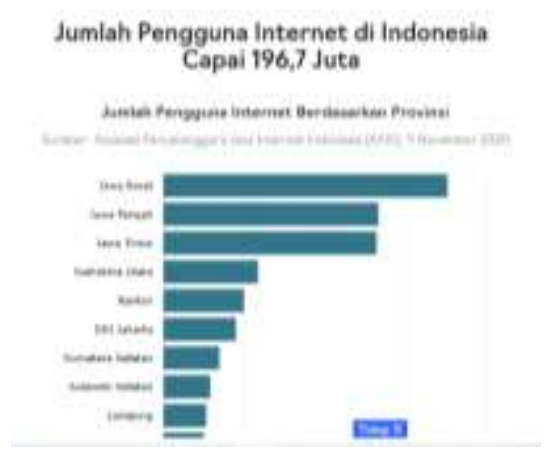

Gambar 2. Pertumbuhan Internet di Indonesia Tahun 2020
Berdasarkan data diatas, jumlah pengguna internet di Indonesia mencapai 196,7 Juta pengguna dengan 3 Provinsi pengguna tertinggi yaitu Jawa Barat sejumlah 35,1 Juta, Jawa Tengah sejumlah 26,5 Juta dan Jawa Timur sejumlah 26,4 Juta (Katadata, 2020). Hal tersebut menjadi potensi yang baik dalam belanja online di Indonesia yang saat ini berkembang pesat. Oleh karena itu, pelaku bisnis harus dapat beradaptasi denan perubahan perilaku pembeli yang lebih menyukai belanja online dengan memaksimalkan dalam pemanfaatan digital marketing. Digital marketing merupakan teknologi yang digunakan dalam membantu dalam proses pemasaran yang bertujuan dalam peningkatan pengetahuan konsumen dengan menyesuaikan kebutuhannya (Ahmad \& Nurmansyah, 2019). Digital marketing dalam sektor bisnis dapat memudahkan interaksi antara penjual dan pembeli. Penjual dimudahkan dalam melakukan pelayanan hingga promosi kepada pembeli dengan tujuan memenuhi kebutuhan sehari - hari dengan waktu yang cukup singkat. Perkembangan teknologi digital berbasis internet dan digital marketing dalam dunia perekonomian UKM dapat menjangkau dan memperluas konsumen yang pada mulanya mengalami keterbatasan dari jarak, waktu dan cara berkomunikasi (Laksana \& Dharmayanti, 2018). Bisnis dapat bertahan dengan peningkatan omset di tengah kondisi kebijakan - kebijakan pemerintah dalam menghadapi pandemi Covid19 dengan adanya digital marketing. Omset merupakan jumlah dari proses penjualan yang berupa produk barang atau jasa dan dihitung secara menyeluruh dalam waktu tertentu (Jatmika et al., 2017). Namun, disisi lain digital marketing memiliki beberapa kelemahan diantaranya mudah ditiru oleh orang lain, mudah disalahgunakan oleh orang lain, dapat memiliki reputasi yang kurang baik ketik ada respon negative serta tidak semua orang dapat menggunakan teknologi digital (Febriyantoro \& Arisandi, 2018).

Pelaku UKM juga menggunakan sosial media dan marketplace dalam strategi 
pemasaranya. Media sosial merupakan alat komunikasi yang berbasis internet yang memberikan infromasi di dalamnya (Maria Nila Anggia \& Muhammad Rifki Shihab, 2019). Media sosial juga di manfaatkan dalam sebuah transaksi penjualan. Beberapa media sosial yang digunakan oleh masyarakat yaitu Facebook, Instagram, TikTok. Market Place sebagai salah satu media untuk memasarkan sebuah bisnis dapat juga kita manfaatkan sebagai ladang untuk mencari uang. Market place adalah salah satu model e-commerce yang berfungsi sebagai perantara antara penjual dan pembeli. Platform ecommerce ini menjadi strategi secara eksternal untuk mengoptimalkan bisnis (Imron \& Syafa, 2020) Market place sebagai media yang benarbenar menjadi peluang jika dapat memanfaatkannya. Penjual yang memanfaatkan untuk menjual produk di marketplace hanya perlu menyiapkan pesanan. Semua aktivitas lain seperti pengelolaan website sudah diurus oleh platform tersebut. Aplikasi dari market place menjadi tempat untuk menjual produk tanpa menyulitkan penjual (Nugroho, 2021). Marketplace yang sering digunakan oleh masyarakat yaitu Shopee, Lazada, dan Tokopedia.

Dalam membangkitkan perekonomian UKM akibat pandemic membutuhkan upaya upaya yang cukup besar. Deva Bag adalah usaha mikro kecil dengan produk tas yang berada di Desa Jiken Kecamatan Tulangan Kabupaten Sidoarjo yang merasakan dampak dari adanya pandemic virus ini. Dampak yang dirasakan Deva Bag yaitu penurunan jumlah permintaan tas yang mengakibatkan turunnya omset hingga $60 \%$ serta tertinggalnya pemahaman mengenai digital marketing dan masih menggunakan strategi pemasaran secara tradisional dengan jangkauan konsumen yang rendah. Berdasarkan beberapa penjelasan di atas, kami tertarik untuk melakukan penelitian mengenai Peran Digital Marketing dalam Upaya Peningkatan Omset Penjualan di Era Pandemi Covid-19 (Studi Kasus UKM Deva Bag Desa Jiken Kecamatan Tulangan). Penelitian ini dimaksudkan untuk menganalisa strategi yang digunakan oleh UKM Deva Bag untuk meningkatkan omset di era pandemi covid-19. Dan setelah menganalisa mengenai strategistrategi yang digunakan, kami tertarik untuk memberikan edukasi mengenai digital marketing kepada UKM Deva Bag agar dapat bertahan dengan peningkatan omset di era pandemi covid19 dengan memanfaatkan sosial media hingga marketplace. Kegiatan ini sebagai bentuk pengabdian kami terhadap masyarakat setempat dalam program Kuliah Kerja Nyata Tanggap Covid-19 UIN Sunan Ampel Surabaya.

\section{Tujuan dan Manfaat Kegiatan}

Tujuan penelitian ini ialah untuk mengetahui bagaimana digital marketing dapat menjadi alat bantu dalam meningkatkan omset UKM Deva Bag di Desa Jiken Kecamatan Tulangan di era Pandemi Covid-19. Penelitian ini juga berfungsi mengetahui pengaruh digital marketing terhadap UKM Deva Bag di Desa Jiken Kecamatan Tulangan di era Pandemi Covid-19.

Manfaat dari peneitian ini terbagi menjadi dua, yaitu:

1. Secara Teoritis

Penelitian ini diharapkan dapat menambah wawasan serta pengetahuan para pembaca, khususnya mengenai peran digital marketing terhadap UKM di era Pandemi Covid-19.

2. Secara Praktis

a. Bagi Peneliti

Dapat mengetahui tingkat pemahaman masyarakat mengenai digital marketing serta mengetahui pengaruh digital marketing terhadap UKM di era Pandemi Covid-19.

b. Bagi Masyarakat

Dapat dijadikan sebagai informasi serta acuan dalam peningkatan omset, khususnya dalam penggunaan digital marketing.

\section{METODE PELAKSANAAN}

\section{Sasaran kegiatan}


dari kegiatan ini yaitu adanya peningkatan pemahaman mengenai strategi alternative yang digunakan di era pandemic covid-19 yaitu dengan strategi digital marketing.

\section{Lokasi kegiatan}

Lokasi kegiatan penelitian dan pelatihan di Desa Jiken Kecamatan Tulangan Kabupaten Sidoarjo

\section{Metode yang digunakan :}

Metode yang digunakan dalam penelitian ini adalah:

a) Mengumpulkan data melalui wawancara mendalam dari subjek penelitian mengenai data yang dibutuhkan dalam penelitian ini yaitu mengenai keadaan UKM Deva Bag di era pandemi Covid-19 dan kemudian dianalisis sehingga dapat menggambarkan keadaan sesuai fakta di lapangan secara jelas dan sedetail mungkin dari orang yang diamati (Yulianto \& Nugraheni, 2021).

b) Melakukan action research berupa penyuluhan atau memberikan pembelajaran (edukasi) terhadap subjek penelitian untuk peningkatan kapasitas melalui kegiatan penyuluhan dan pelatihan digital marketing (Tirayoh \& Lintong, 2020).

c) Melakukan wawancara kembali untuk mengetahui keadaan UKM Deva Bag di Desa Jiken setelah adanya edukasi tentang digital marketing.

\section{HASIL DAN PEMBAHASAN}

Kegiatan Kuliah Kerja Nyata yang dilakukan kepada UKM Deva Bag di Desa Jiken Kecamatan Tulangan dilakukan dengan memberikan pemahaman edukasi hingga praktek mengeni digital marketing. Kegiatan ini berlangsung selama tiga hari pada tanggal $2-4$ Agustsus 2021. Pada hari pertama pendampingan pemahaman mengenai digital marketing hingga branding. Sebelumnya, UKM ini belum memiliki logo. Pembuatan logo hingga nama brand dilakukan pada tahap ini yang dimulai dari menentukan nama. Logo disesuaikan dengan permintaan pemilik UKM yang ingin menonjolkan produk tas didalamnya. Dampak

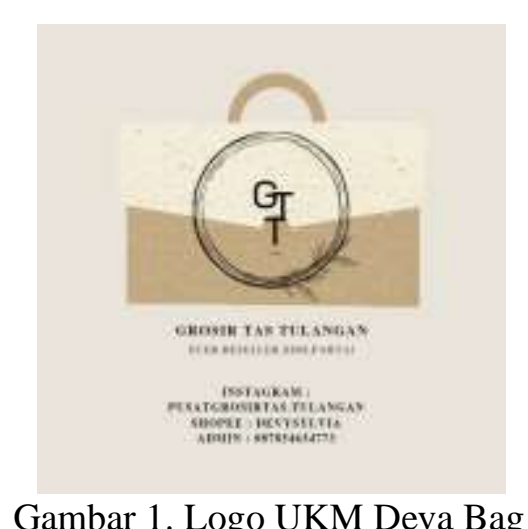

Gambar 1. Logo UKM Deva Bag

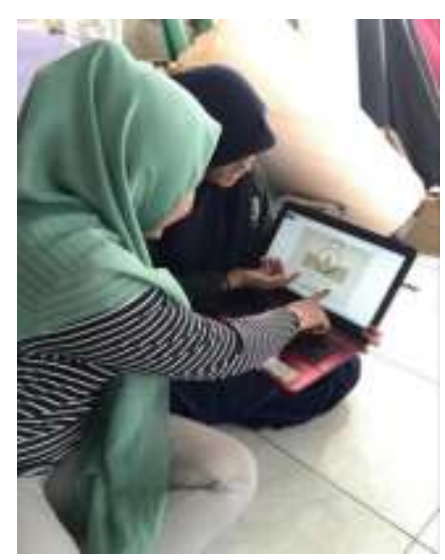

Gambar 2. Proses pembuatan logo

Pada hari kedua, pendampingan memberikan pemahaman mengenai sosial media. Pembuatan Instagram, TikTok hingga Facebook dilakukan agar konsumen mengetahui dan tertarik pada produk tas yang dihasilkan oleh Deva Bag. Selanjutnya yakni pemahaman mengenai marketplace, dikarenakan saat ini marketplace seperti shopee sangat digemari oleh konsumen karena mempermudah dalam mencari kebutuhan yang sedang dicari dan dapat memperluas jangkauan pemasaran produk. Selain itu, proses pembayaran yang banyak pilihan dapat mempermudah konsumen bertransaksi. Pada saat pelaksanaan praktek, pemilik UKM Deva Bag mempunyai antusiasme yang cukup besar, apabila ada hal yang kurang dipahami langsung bertanya. Dampak yang dihasilkan 
yakni semakin terjangkaunya produk yang dihasilkan Deva Bag kepada konsumen.
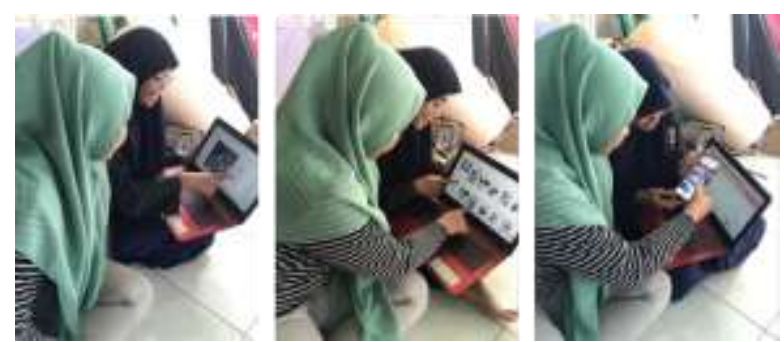

Gambar 3. Pemahaman dan praktek marketplace dan sosial media

Pada hari ketiga, pemahaman dan praktek mengenai foto produk. Hal tersebut dapat berdampak kepada UKM agar konsumen lebih tertarik sehingga dapat megakibatkan peningkatan omset dengan memanfaatkan ketertarikan konsumen.
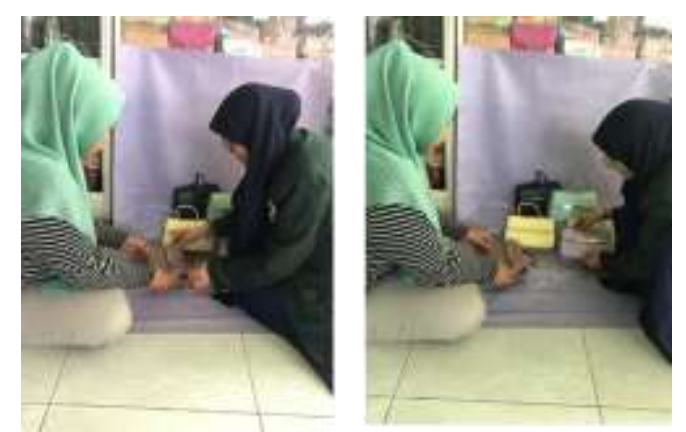

Gambar 4. Praktek foto produk

\section{Pemahaman mengenai digital marketing}

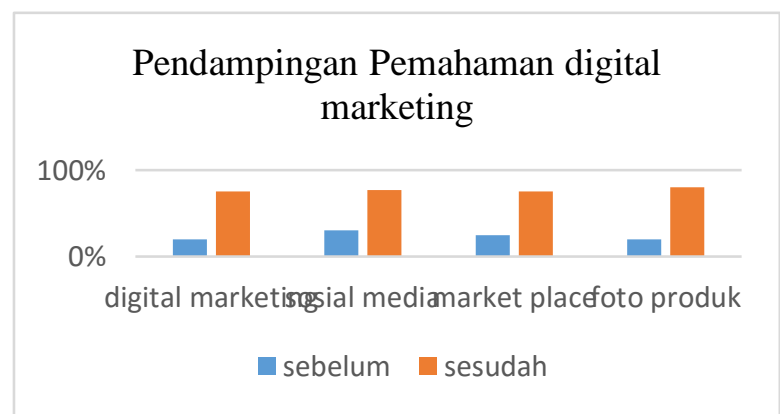

Gambar 5. Grafik perkembangan pemahaman digital marketing

Sejak berdirinya hingga saat ini UKM Deva Bag masih menggunakan strategi penjualan tradisional yaitu dengan hanya menyuplai toko besar tanpa mengikuti perkembangan teknologi digital. Oleh karena itu, di era pandemic saat ini UKM Deva Bag merasakan dampak penurunan omset yang signifikan dari adanya beberapa kebijakan pemerintah. Dari grafik diatas menunjukkan bahwa peningkatan pengetahuan UKM mengenai digital marketing yaitu sebesar $55 \%$. Pentingnya pemahaman mengenai dasar digital marketing mengharuskan UKM cepat memahami materi edukasi. Selanjutnya yakni peningkatan pemahaman mengenai sosial media yaitu sebesar $47 \%$, peningkatan pemahaman marketplace sebesar $50 \%$ dan peningkatan pemahaman foto produk sebesar $60 \%$. Menurut UKM Deva Bag mempelajari mengenai digital marketing dengan metode pendampingan praktek lebih mudah dimengerti dan diingat. Sehingga edukasi mengenai digital marketing hingga dapat dipahami dengan baik oleh pemilik UKM Deva Bag.

\section{Besaran omset selama pandemic}

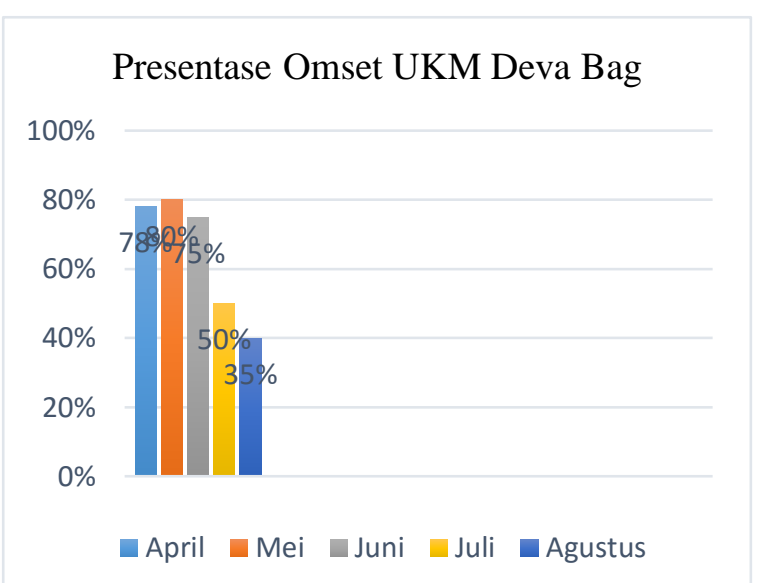

Gambar 6. Presentase Omset UKM Deva Bag

Dari grafik diatas dapat disimpulkan bahwa selama pandemic, UKM Deva Bag hampir mengalami kebangkrutan karena tidak ada produk tas yang dikeluarkan. Hal tersebut dilatarbelakangi oleh beberapa kebijakan pemerintah yang menghambat proses pendistribusian ke luar pulau hingga operasional toko besar yang disuplai UKM ini.

Dengan adanya pemahaman digital marketing, UKM Deva Bag cukup signifikan dalam kenaikan omset sejumlah $30 \%$. Hal tersebut didukung sosial media hingga marketplace. 
Hal tersebut memiliki dampak positif terhadap usaha di era pandemic covid-19 saat ini.

\section{KESIMPULAN DAN SARAN}

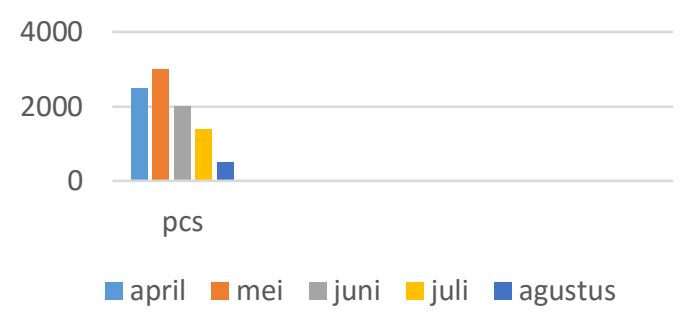

Gambar 7. Presentase produk UKM Deva Bag yang terjual

Dari grafik diatas, dapat disimpulkan bahwa naik turunnya omset berbanding lurus dengan produk yang dikeluarkan. Setelah adanya pemahaman dan penerapan digital marketin, omset UKM Deva Bag perlahan sesuai dengan harapan sehingga dapat beroperasi seperti semula dengan ketersediaan lapangan pekerjaan untuk warga sekitar.

Dengan adanya pendampingan mengenai digital marketing, UKM Deva Bag dapat memasarkan produknya sendiri melalui media sosial hingga market place sehingga UKM ini tidak tergantung dengan toko - toko yang disuplai. Selain itu, Deva Bag dapat memahami bagaimana cara membuat produk terlihat menarik oleh konsumen dalam foto produk.

\section{Sosial media dan marketplace Usaha}
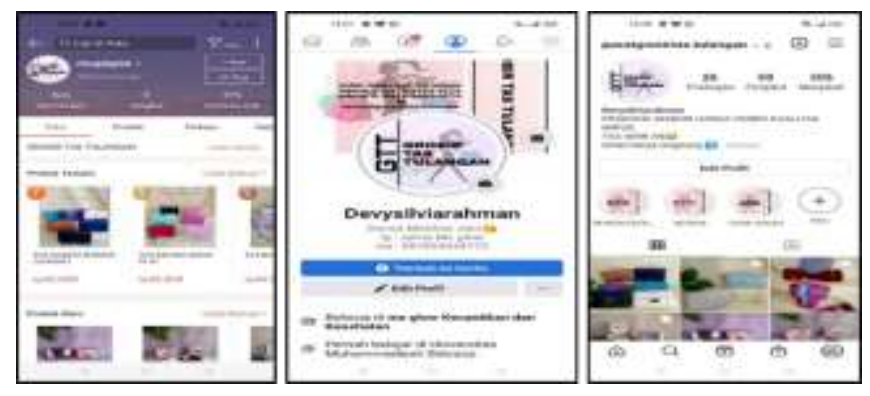

Gambar 8. Sosial media dan marketplace UKM Deva Bag

Dengan adanya perbaikan manajemen pemasaran dapat mempengaruhi peningkatan jumlah pelanggan yang berimbas terhadap peningkatan omset penjualan (Harto et al., 2019).
Peningkatan omset UKM Deva Bag dengan digital marketing dapat membantu untuk tetap bertahan di era pandemic covid-19. Strategi yang digunakan dengan melalui sosial media hingga marketplace. Dengan adanya digital marketing, UKM Deva Bag dapat menjangkau konsumen lebih luas tanpa kontak fisik di era pandemic covid-19.

\section{UCAPAN TERIMAKASIH}

Terimakasih diucapkan kepada Dosen Pembimbing Lapangan Ibu Dr. Nabiela Naily, S.Si, M.HI yang telah membantu dan membimbing kegiatan Kuliah Kerja Nyata (KKN) ini, UKM Deva Bag Desa Jiken Kecamatan Tulangan yang menjadi subjek dari kegiatan ini.

\section{DAFTAR PUSTAKA}

Ahmad, A., \& Nurmansyah, H. (2019). Abdul Ahmad Hafidh Nurmansyah. 16(1), 74-86.

Dinas Komunikasi dan Informatika Kabupaten Sidoarjo. (2021). Peta Sebaran Covid-19. Www.Covid-19.Sidoarjokab.Go.Id. https://covid19.sidoarjokab.go.id/

Febriyantoro, M. T., \& Arisandi, D. (2018). Pemanfaatan Digital Marketing Bagi Usaha Mikro, Kecil Dan Menengah Pada Era Masyarakat Ekonomi Asean. JMD: Jurnal Riset Manajemen \& Bisnis Dewantara, 1(2), 61-76. https://doi.org/10.26533/jmd.v1i2.175

Harto, D., Pratiwi, S. R., Utomo, M. N., \& Rahmawati, M. (2019). Penerapan Internet Marketing Dalam Meningkatkan Pendapatan Pada UMKM. JPPM (Jurnal Pengabdian Dan Pemberdayaan Masyarakat), 3(1), 39. https://doi.org/10.30595/jppm.v3i1.3033

Imron, A., \& Syafa, M. (2020). Revitalisasi Home Industry Berbasis Modal Sosial Sebagai Strategi Ketahanan Ekonomi Menghadapi Pandemi Covid-19. Prosiding 
Seminar Nasional Problematika Sosial Pandemi Covid-19, 97-101.

Jatmika, S., Aprilianto, T., \& Prasetyo, B. P. T. (2017). E-Marketing Dengan Media Jejaring Sosial Untuk Peningkatan Omset Penjualan. Seminar Nasional Sistem Informasi 2017, 1(1), 646-654.

Katadata. (2020). Pertumbuhan Internet di Indonesia Tahun 2020. Www.Databoks.Katadata.Co.Id. https://databoks.katadata.co.id/datapublish/ 2020/11/11/jumlah-pengguna-internet-diindonesia-capai-1967-juta.

Kementerian Koperasi dan Usaha Kecil dan menengah. (2020). Kontribusi UMKM Terhadap PDB 2010-2020. Www.Lokadata.Id. https://lokadata.id/data/kontribusi-umkmterhadap-pdb-2010-2020-1611277587

Komite Penanganan Covid-19 dan Pemulihan Ekonomi Nasional. (2021). Peta Sebaran Covid-19. Www.Covid19.Go.Id. https://covid19.go.id/peta-sebaran-covid19

Laksana, D., \& Dharmayanti, D. (2018). Pengaruh Digital Marketingterhadap Organizational Performance Denganintellectualcapital Danperceived Quality Sebagai Variabel Intervening Pada Industri Hotel Bintang Empat Di Jawa Timur. Jurnal Manajemen Pemasaran, 12(1), 10. https://doi.org/10.9744/pemasaran.12.1.1024

Maria Nila Anggia, \& Muhammad Rifki Shihab. (2019). Strategi Media Sosial Untuk Pengembangan Umkm. Jurnal Terapan Teknologi Informasi, 2(2), 159-170. https://doi.org/10.21460/jutei.2018.22.125

Nugroho, A. (2021). Framework To Sell Item in Online Market Place in Indonesia. International Journal of Open Information Technologies, 9(1).

Tirayoh, V., \& Lintong, D. (2020). Penguatan Ekonomi Rumah Tangga pada Masa Pandemi Covid-19 di Kelurahan Sario Kota Baru Kecamatan Sario Kota Manado. VIVABIO: Jurnal Pengabdian Multidisiplin, 2(2), 34. https://doi.org/10.35799/vivabio.2.2.2020. 31187

Yulianto, D., \& Nugraheni, A. S. (2021). Efektivitas Pembelajaran Daring Dalam Pembelajaran Bahasa Indonesia. Decode:
Jurnal Pendidikan Teknologi Informasi, 1(1), $33-42$. https://doi.org/10.51454/decode.v1i1.5 